\title{
An Expeditious Enantioselective Total Synthesis of Valilactone
}

Yikang $\mathrm{Wu}^{*}$ and Ya-Ping Sun

State Key Laboratory of Bio-organic \& Natural Products Chemistry, Shanghai Institute of Organic Chemistry, Chinese Academy of Sciences, 354 Fenglin Road, Shanghai 200032, China.

E-mail: yikangwu@mail.sioc.ac.cn

Table of Contents

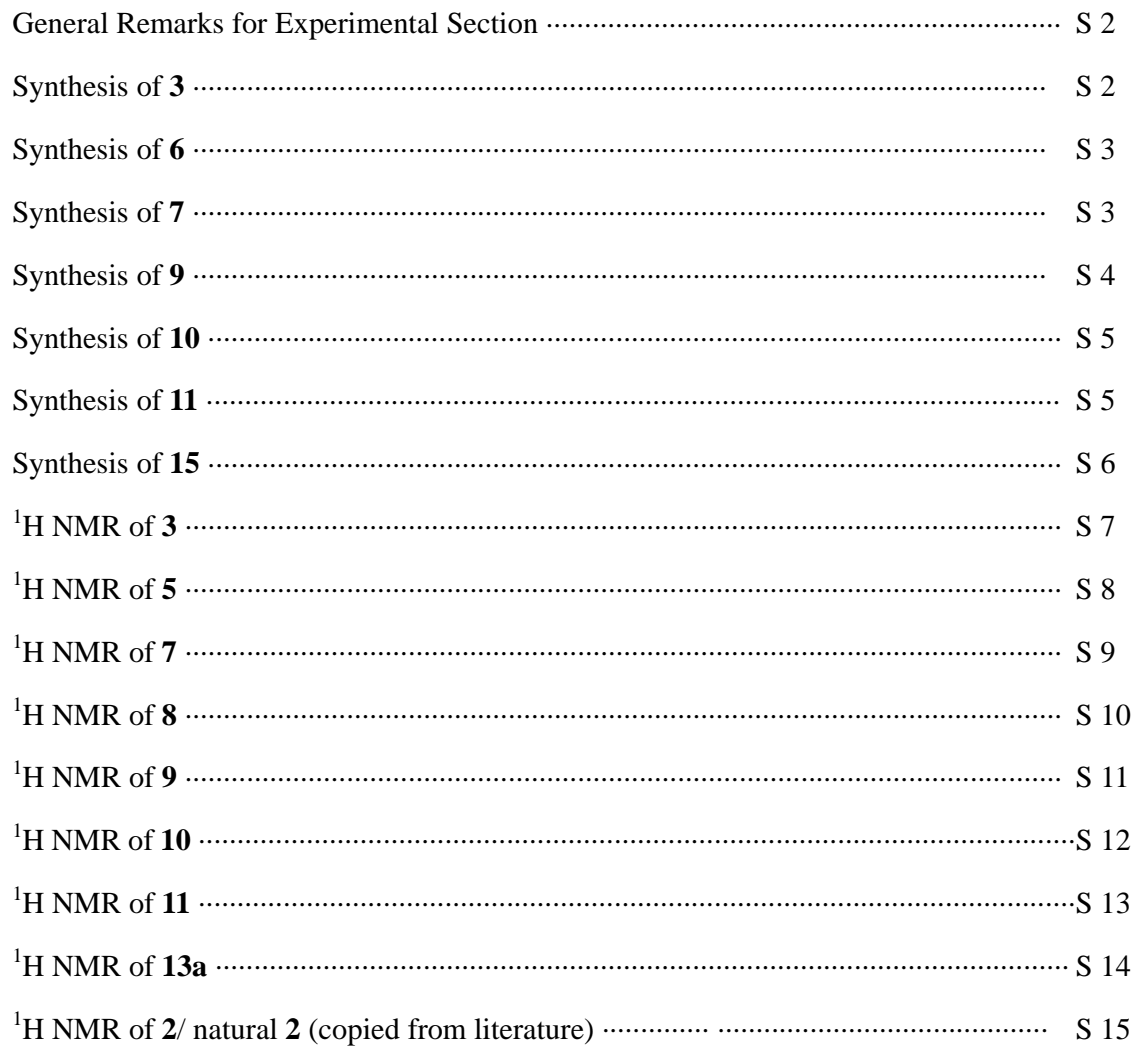


General remarks for Experimental Section: The anhydrous/reagents involved in the moisture/air sensitive experiments were dried as follows. THF: distilled from $\mathrm{Na}$ wire $/ \mathrm{Ph}_{2} \mathrm{CO}$ under $\mathrm{N}_{2}$ prior to use. $\mathrm{CH}_{2} \mathrm{Cl}_{2}$, pyridine, $\mathrm{NEt}_{3}, \mathrm{TMEDA}$, and DMF: distillated over $\mathrm{CaH}_{2}$ under $\mathrm{N}_{2}$ prior to use. Column chromatography was performed with silica gel (300-400 mesh). NMR spectra were recorded in $\mathrm{CDCl}_{3}$ on a spectrometer operating at $300 \mathrm{MHz}$ for proton unless otherwise stated. IR spectra were recorded on an FT-IR spectrometer. MS and HRMS experiments were performed on a high/low resolution magnetic sector mass spectrometer. Optical rotations were measured on a precision automated polarimeter. All yields given refer to as isolated yields.

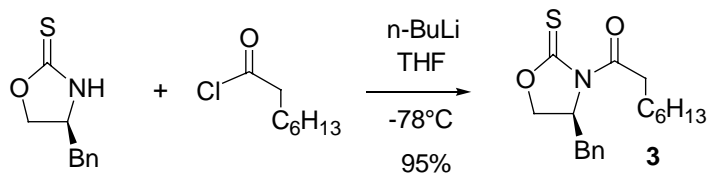

Synthesis of compound 3. n-BuLi $(10.0 \mathrm{~mL}, 15.0 \mathrm{mmol})$ was added dropwise to a solution of (S)-4-benyl-oxazolidine- 2-thione (1.355 g, $6.90 \mathrm{mmol})$ in dry THF (20 mL) stirred at $-78{ }^{\circ} \mathrm{C}$ under $\mathrm{N}_{2}$. The red solution was then stirred at $-78{ }^{\circ} \mathrm{C}$ for 20 min before octanoyl chloride (2.67 mL, $15.6 \mathrm{mmol})$ was introduced dropwise. Stirring was continued at the same temperature for $15 \mathrm{~min}$, then was kept at ambient temperature for $1 \mathrm{~h}$. the reaction mixture was diluted with $\mathrm{Et}_{2} \mathrm{O}(200 \mathrm{~mL})$ and washed successively with aq. sat. $\mathrm{NaHCO}_{3}(50 \mathrm{~mL}), \mathrm{H}_{2} \mathrm{O}(50 \mathrm{~mL})$, brine $(50 \mathrm{~mL})$, and dried over $\mathrm{Na}_{2} \mathrm{SO}_{4}$. Removal of the solvents and the drying agent left an oily residue, which was chromatographed (7:1 n-hexane/EtOAc) on silica gel to give 3 as a pale yellow oil (2.089 g, 95\%): $[\alpha]_{\mathrm{D}}{ }^{24}$ $+52.3^{\circ}$ (c 1.00, $\left.\mathrm{CHCl}_{3}\right) .{ }^{1} \mathrm{H} \mathrm{NMR}\left(300 \mathrm{MHz}, \mathrm{CDCl}_{3}\right) \delta$ 7.36-7.21 (m, 5H), 4.93 (m, 1H), 4.39-4.25 (m, 2H), 3.44-3.18 (m, 3H), 2.76 (dd, $J=10,13.2$ Hz, 1H), 1.80-1.60 (m, 2H), 1.44-1.15 (m, 8H), 0.96-0.86 (m, 3H); FT-IR (film) 1701, 1454, 1366, 1193, $702 \mathrm{~cm}^{-1}$; ESI-MS m/z $342.1\left([\mathrm{M}+\mathrm{Na}]^{+}\right)$. ESI-HRMS Calcd for $\mathrm{C}_{18} \mathrm{H}_{25} \mathrm{NO}_{2} \mathrm{SNa}\left([\mathrm{M}+\mathrm{Na}]^{+}\right)$ 342.1498; found 342.1497. 


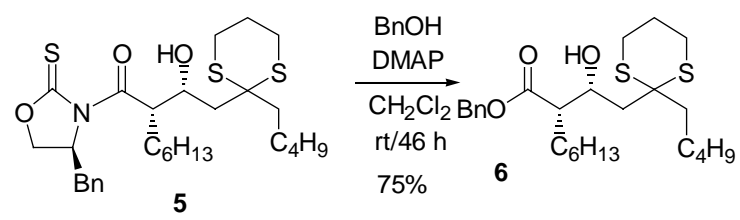

Synthesis of compound 6. To a solution of 5 (88 mg, $0.160 \mathrm{mmol})$ in dry $\mathrm{CH}_{2} \mathrm{Cl}_{2}(1.1$ $\mathrm{mL})$ stirred in an ice-water bath were added $\mathrm{BnOH}(0.05 \mathrm{~mL}, 0.48 \mathrm{mmol})$ and DMAP (10 mg, $0.08 \mathrm{mmol}$ ). The mixture was then stirred at the ambient temperature until TLC showed completion of the reaction (ca. $46 \mathrm{~h}$ ). The reaction mixture was diluted with diethyl ether, washed with $2 \mathrm{~N} \mathrm{HCl}$, water, and brine, and dried over anhydrous $\mathrm{Na}_{2} \mathrm{SO}_{4}$. The crude residue after removal of the solvents was chromatographed on silica gel (8:1 $n$-hexane/EtOAc) to afford $\mathbf{6}^{11 \mathrm{~b}}$ as a colorless oil (56 mg, 75\% yield).

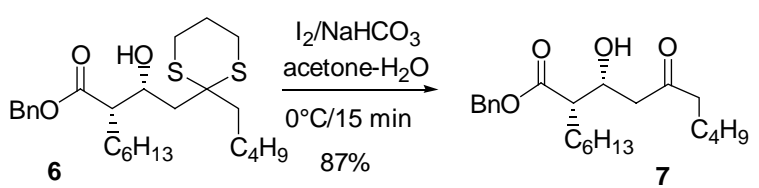

Synthesis of compound 7. To a solution of 6 (114 $\mathrm{mg}, 0.245 \mathrm{mmol})$ in acetone (2.4 mL) and water $(0.6 \mathrm{~mL})$ stirred in an ice-water bath were added in turn $\mathrm{NaHCO}_{3}(185 \mathrm{mg}, 2.2$ $\mathrm{mmol}$ ) and $\mathrm{I}_{2}(187 \mathrm{mg}, 0.74 \mathrm{mmol})$. When TLC showed completion of the reaction (ca. 15 min) the reaction mixture was diluted with diethyl ether and washed with aq. sat. $\mathrm{Na}_{2} \mathrm{~S}_{2} \mathrm{O}_{3}$. The phases were separated. The aqueous phase was back extracted thrice with diethyl ether. The combined organic phases were washed with water, brine, and dried over anhydrous $\mathrm{Na}_{2} \mathrm{SO}_{4}$. The residue after removal of the drying agent and the solvent was chromatographed on silica gel (6:1 n-hexane/EtOAc) to give 7 as a colorless oil (80 mg, 87\% yield): $[\alpha]_{\mathrm{D}}{ }^{24}+12.2^{\circ}\left(c\right.$ 1.45, $\left.\mathrm{CHCl}_{3}\right) .{ }^{1} \mathrm{H}$ NMR (300 MHz, $\left.\mathrm{CDCl}_{3}\right) \delta$ 7.36-7.26 (m, 5H), 5.16 (s, 2H), 4.22-4.10 (m, 1H), 3.44-3.38 (m, 1H), 2.62-2.43 (m, 3H), 2.32 (t, $J$ 
$=7.5 \mathrm{~Hz}, 2 \mathrm{H}), 1.68-1.50(\mathrm{~m}, 4 \mathrm{H}), 1.33-1.23(\mathrm{~m}, 12 \mathrm{H}), 0.91-0.84(\mathrm{~m}, 6 \mathrm{H})$; FT-IR (film) 3372, 2926, 2858, 1724, 1711, 1455, 1382, 1159, $697 \mathrm{~cm}^{-1}$; ESI-MS m/z $377.2\left([\mathrm{M}+\mathrm{H}]^{+}\right)$. ESI-HRMS calcd for $\mathrm{C}_{23} \mathrm{H}_{36} \mathrm{O}_{4} \mathrm{Na}\left([\mathrm{M}+\mathrm{Na}]^{+}\right)$399.2506; found 399.2506.

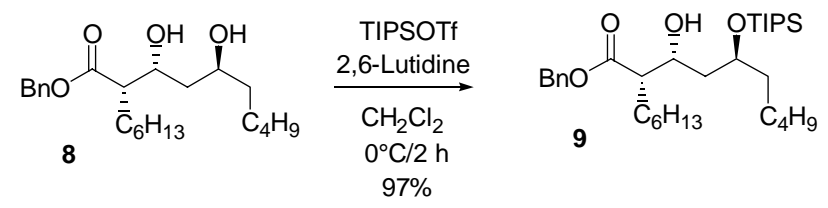

Synthesis of compound 9. To a solution of 8 (44 $\mathrm{mg}, 0.117 \mathrm{mmol})$ in dry $\mathrm{CH}_{2} \mathrm{Cl}_{2}(1.2$ $\mathrm{mL})$ stirred in an ice-water bath were added 2,6-lutidine $(0.041 \mathrm{~mL}, 0.35 \mathrm{mmol})$ and TIPSOTf (0.047 mL, $0.18 \mathrm{mmol})$. Stirring was continued at the same temperature until TLC showed completion of the reaction (ca. 1 h). The reaction mixture was diluted with diethyl ether $(150 \mathrm{~mL})$, washed with aq. saturated $\mathrm{CuSO}_{4}(20 \mathrm{~mL} \times 4), \mathrm{H}_{2} \mathrm{O}(20 \mathrm{~mL})$, brine (20 mL), and dried over $\mathrm{Na}_{2} \mathrm{SO}_{4}$. After removal of the solvent, the residue was chromatographed on silica gel (10:1 $n$-hexane/EtOAc) to afford 9 as a colorless oil (60 mg, $97 \%$ yield): $[\alpha]_{\mathrm{D}}{ }^{27}+4.6^{\circ}\left(c \mathrm{c} .0, \mathrm{CHCl}_{3}\right) .{ }^{1} \mathrm{H}$ NMR $\left(500 \mathrm{MHz}, \mathrm{CDCl}_{3}\right) \delta$ 7.40-7.31 (m, 5H), 5.14 (d, $J=12.3 \mathrm{~Hz}, 1 \mathrm{H}), 5.07$ (d, $J=12.3 \mathrm{~Hz}, 1 \mathrm{H}), 4.15-4.05$ (m, 2H), 3.96 (s, $1 \mathrm{H}$, OH), 2.50-2.46 (m, 1H), 1.80-1.43 (m, 6H), 1.35-1.15 (m, 14H), 1.15-0.95 (m, 21H), 0.88 (br t, $J=7 \mathrm{~Hz}, 3 \mathrm{H}$ ), 0.85 (br t, $J=7 \mathrm{~Hz}, 3 \mathrm{H}$ ); FT-IR (film) 3484, 2930, 2866, 1735, 1464, 1380, 1159, $679 \mathrm{~cm}^{-1}$; ESI-MS m/z $535.3\left([\mathrm{M}+\mathrm{H}]^{+}\right)$. ESI-HRMS calcd for $\mathrm{C}_{32} \mathrm{H}_{58} \mathrm{O}_{4} \mathrm{SiNa}$ $\left([\mathrm{M}+\mathrm{Na}]^{+}\right)$557.3997; found 557.3996. 


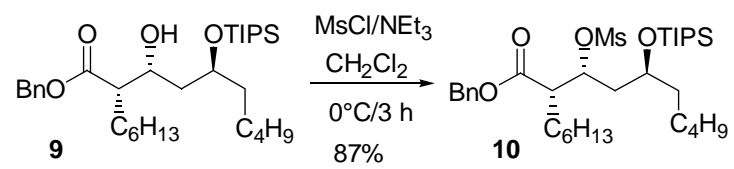

Synthesis of compound 10. $\mathrm{NEt}_{3}(16 \mu \mathrm{L}, 0.36 \mathrm{mmol})$ and $\mathrm{MsCl}(8 \mu \mathrm{L}, 0.096 \mathrm{mmol})$ was added dropwise to a solution of $9(40 \mathrm{mg}, 0.075 \mathrm{mmol})$ in dry $\mathrm{CH}_{2} \mathrm{Cl}_{2}(0.75 \mathrm{~mL})$ stirred in an ice-water bath. The cooling bath was then removed and the mixture was stirred at the ambient temperature until TLC showed disappearance of $\mathbf{9}$. The reaction mixture was diluted with diethyl ether, washed with water and brine (twice each), and dried over $\mathrm{Na}_{2} \mathrm{SO}_{4}$. After removal of the solvent, the residue was chromatographed on silica gel (3:1 $n$-hexane/EtOAc) to give $\mathbf{1 0}$ as a colorless oil (40 mg, $87 \%$ yield). $[\alpha]_{\mathrm{D}}{ }^{26}+24.8^{\circ}$ (c 1.4, $\left.\mathrm{CHCl}_{3}\right) .{ }^{1} \mathrm{H}$ NMR $\left(300 \mathrm{MHz}, \mathrm{CDCl}_{3}\right) \delta$ 7.37-7.33 (m, 5H), 5.19 (d, $\left.J=12.6 \mathrm{~Hz}, 1 \mathrm{H}\right), 5.11$ (d, $J=12.2 \mathrm{~Hz}, 1 \mathrm{H}), 5.17-5.09$ (m, 1H), 3.95-3.89 (m, 1H), 2.87 (s, 3H), 2.91-2.85 (m, 1H), $1.91-1.86(\mathrm{~m}, 1 \mathrm{H}), 1.75-1.67(\mathrm{~m}, 2 \mathrm{H}), 1.50-1.41(\mathrm{~m}, 2 \mathrm{H}), 1.37-1.25(\mathrm{~m}, 15 \mathrm{H})$, 1.10-0.93 (m, 21H), 0.88 (br t, $J=6.1 \mathrm{~Hz}, 3 \mathrm{H}$ ), 0.86 (br t, $J=5.9 \mathrm{~Hz}, 3 \mathrm{H}$ ); FT-IR (film) 2929, 2865, 1737, 1464, 1347, 1175, $678 \mathrm{~cm}^{-1}$; ESI-MS m/z $635.3\left([\mathrm{M}+\mathrm{Na}]^{+}\right)$. ESI-HRMS calcd for $\mathrm{C}_{33} \mathrm{H}_{60} \mathrm{O}_{6} \mathrm{SSiNa}\left([\mathrm{M}+\mathrm{Na}]^{+}\right)$635.3772; found 635.3771 .

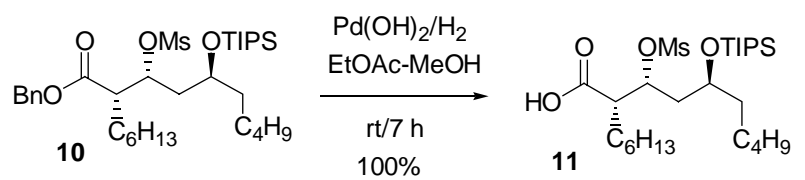

Synthesis of compound 11. A mixture of 10 (480 mg, $0.784 \mathrm{mmol})$ and $20 \% \mathrm{Pd}(\mathrm{OH})_{2}$ (103 mg) in EtOAc (4.0 mL) and $\mathrm{MeOH}(1.0 \mathrm{~mL})$ was stirred under $\mathrm{H}_{2}$ (balloon) for $7 \mathrm{~h}$. The catalyst was removed by filtration. The filtrate and EtOAc washings were evaporated 
to dryness on a rotary evaporator to give crude $\mathbf{1 1}$ as a colorless oil (438 $\mathrm{mg},>100 \%$ yield), which was used as such in the next step. In another run, the crude $\mathbf{1 1}$ was chromatographed on silica gel to give pure 11 (94\% yield), on which the following data were recorded: $[\alpha]_{\mathrm{D}}{ }^{20}+30.2^{\circ}\left(c\right.$ 1.8, $\left.\mathrm{CHCl}_{3}\right) .{ }^{1} \mathrm{H} \mathrm{NMR}\left(300 \mathrm{MHz}, \mathrm{CDCl}_{3}\right) \delta 5.16(\mathrm{dt}, J$ = 3.0, $6.3 \mathrm{~Hz}, 1 \mathrm{H}), 4.05-3.90(\mathrm{~m}, 1 \mathrm{H}), 3.05(\mathrm{~s}, 3 \mathrm{H}), 2.92(\mathrm{dt}, J=9.8,3.8 \mathrm{~Hz}, 1 \mathrm{H})$, 2.03-1.95 (m, 1H), 1.79-1.28 (m, 19H), 1.20-1.02 (m, 21H), 0.89 (br t, $J=5.5$ Hz, 6H); FT-IR (film) a lump around 3500-2500, 2929, 2866, 1713, 1464, 1347, 1175, 905, 678 $\mathrm{cm}^{-1}$; ESI-MS m/z $523.3\left([\mathrm{M}+\mathrm{H}]^{+}\right)$. ESI-HRMS Calcd for $\mathrm{C}_{26} \mathrm{H}_{54} \mathrm{O}_{6} \mathrm{SSiNa}\left([\mathrm{M}+\mathrm{Na}]^{+}\right)$ 545.3303; found 545.3302.
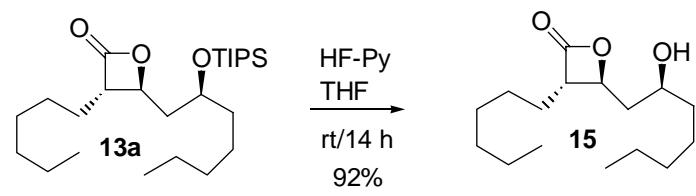

Synthesis of compound 15. A solution of 13a (60 mg, $0.140 \mathrm{mmol})$ and HF-Py (60-70\%, $100 \mathrm{mg}$, са. $0.6 \mathrm{mmol})$ in dry $\operatorname{THF}(1.5 \mathrm{~mL})$ in a 5 -mL plastic vial was stirred at the ambient temperature for $14 \mathrm{~h}$. The reaction mixture was diluted with diethyl ether (100 $\mathrm{mL})$, washed with sat. aq. $\mathrm{CuSO}_{4}(25 \mathrm{~mL} \times 2)$ and $2 \mathrm{~N} \mathrm{HCl}$, and dried over $\mathrm{Na}_{2} \mathrm{SO}_{4}$. After removal of the solvent the residue was chromatographed on silica gel (4:1 $n$-hexane/EtOAc) to give 15 as a colorless oil (35 mg, 92\% yield). [ $\alpha]_{\mathrm{D}}{ }^{25}-15.9^{\circ}$ (c 1.50 , $\left.\mathrm{CHCl}_{3}\right) .{ }^{1} \mathrm{H}$ NMR $\left(300 \mathrm{MHz}, \mathrm{CDCl}_{3}\right) \delta 4.48$ (dt, $\left.J=3.9,6.6 \mathrm{~Hz}, 1 \mathrm{H}\right), 3.86-3.74(\mathrm{~m}, 1 \mathrm{H})$, 3.32 (ddd, $J=3.9,6.7,8.6 \mathrm{~Hz}, 1 \mathrm{H}), 2.07-1.62$ (m, 4H), 1.53-1.30 (m, 16H), 0.90 (t, $J=$ $5.2 \mathrm{~Hz}, 3 \mathrm{H}$ ), 0.89 (t, $J=5.9 \mathrm{~Hz}, 3 \mathrm{H}$ ); FT-IR (film) 3469, 2929, 2858, 1820, 1466, 1379, 1124, $814 \mathrm{~cm}^{-1}$; ESI-MS m/z $271.2\left([\mathrm{M}+\mathrm{H}]^{+}\right)$. Anal. calcd for $\mathrm{C}_{16} \mathrm{H}_{30} \mathrm{O}_{3}$ : C, 71.07; $\mathrm{H}$, 11.18. Found C, 70.75; H, 11.16. 

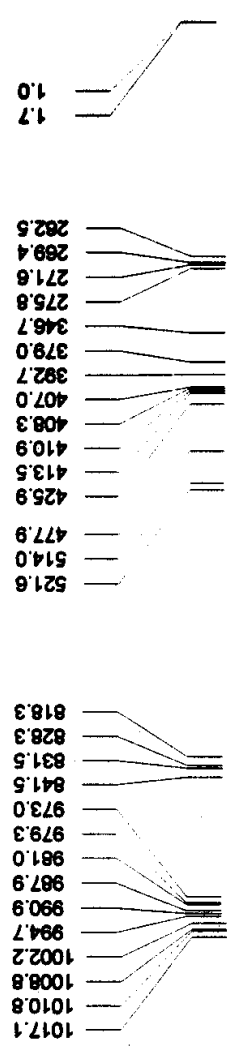

$16821+\ldots$

c'sezt

s.662 -

roszl -

root -

$=$

6 6 $62 t-$

9 28t -

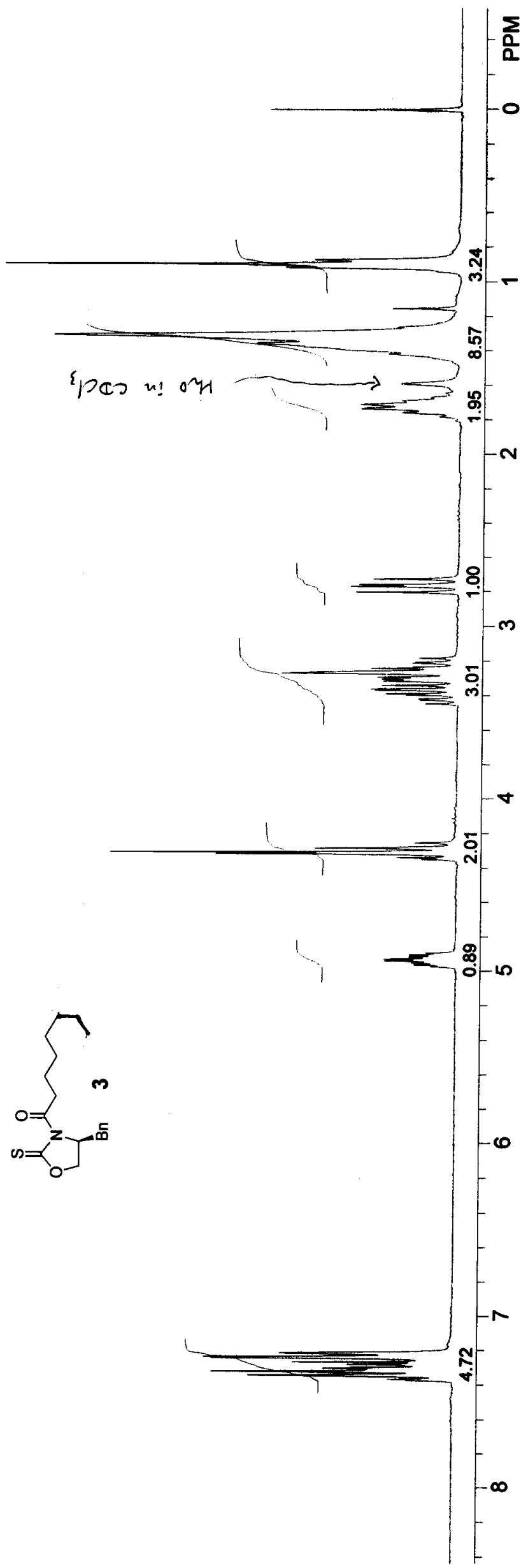

เS9เ2

$9+1 L L Z$
S. $C \angle L Z$

g.08L2

8.z8LL

96812

6812

$66 \mathrm{LC}$

8.9612
19612

1' 12062

0 tozz

sozz -

lolez - 

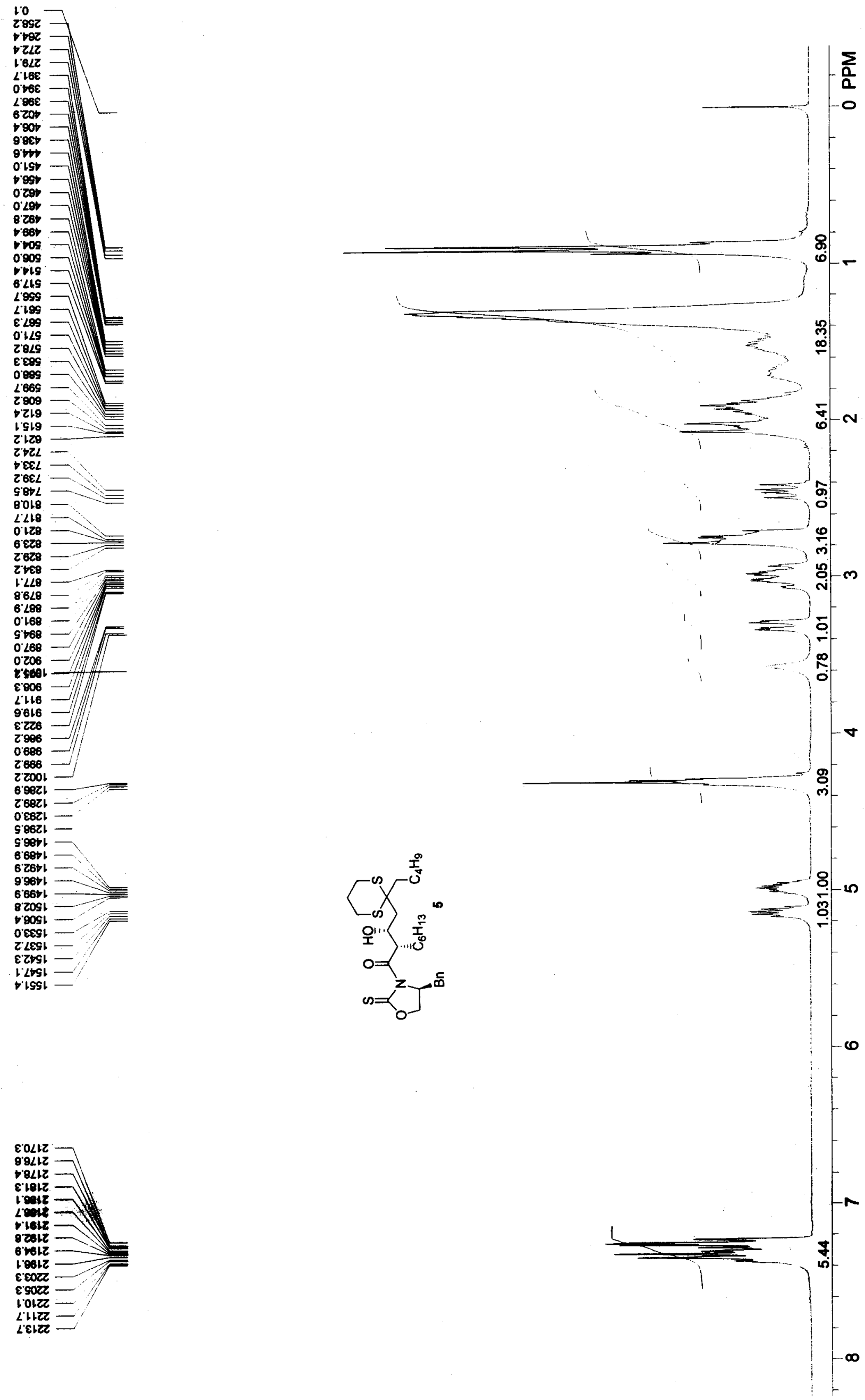

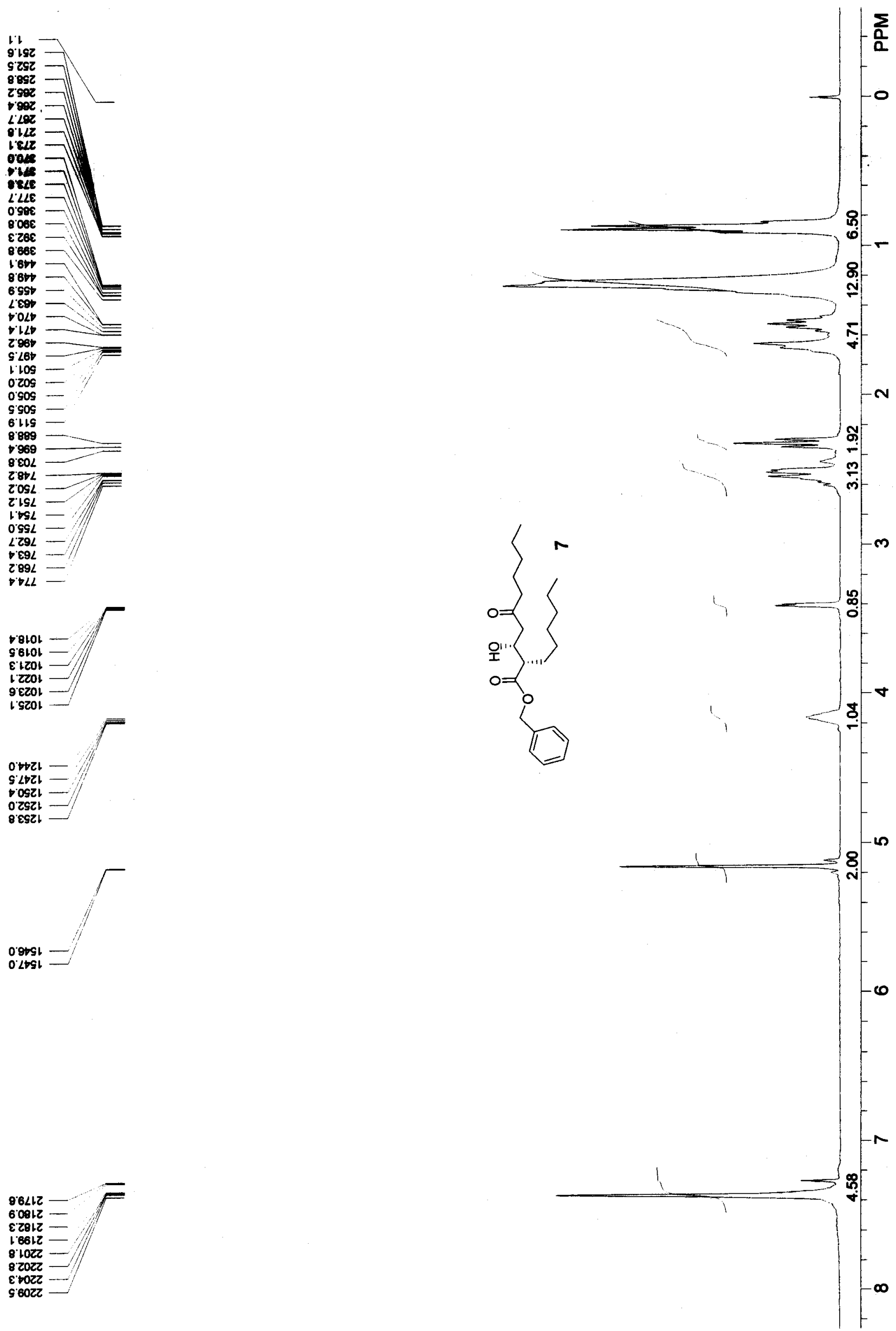

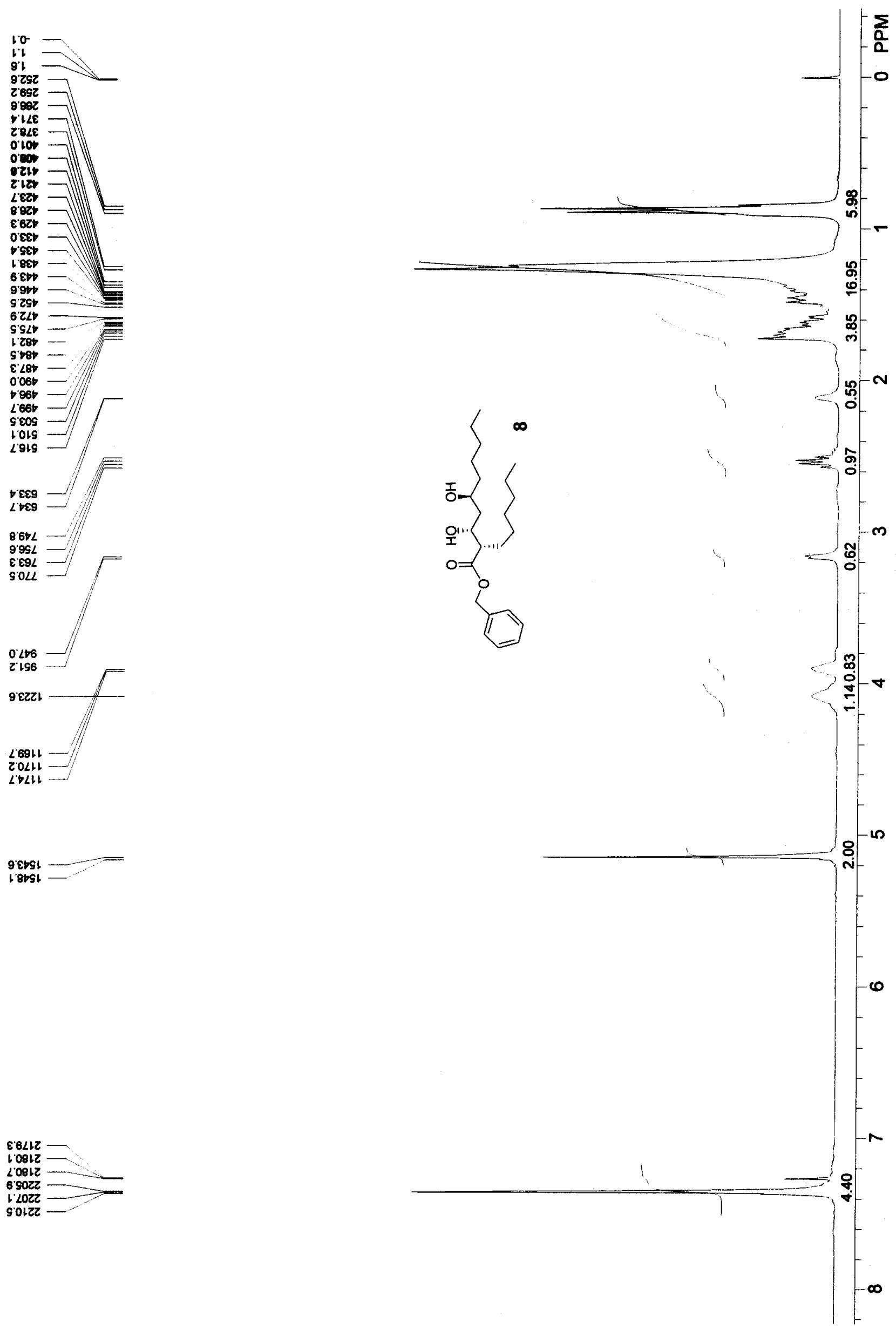

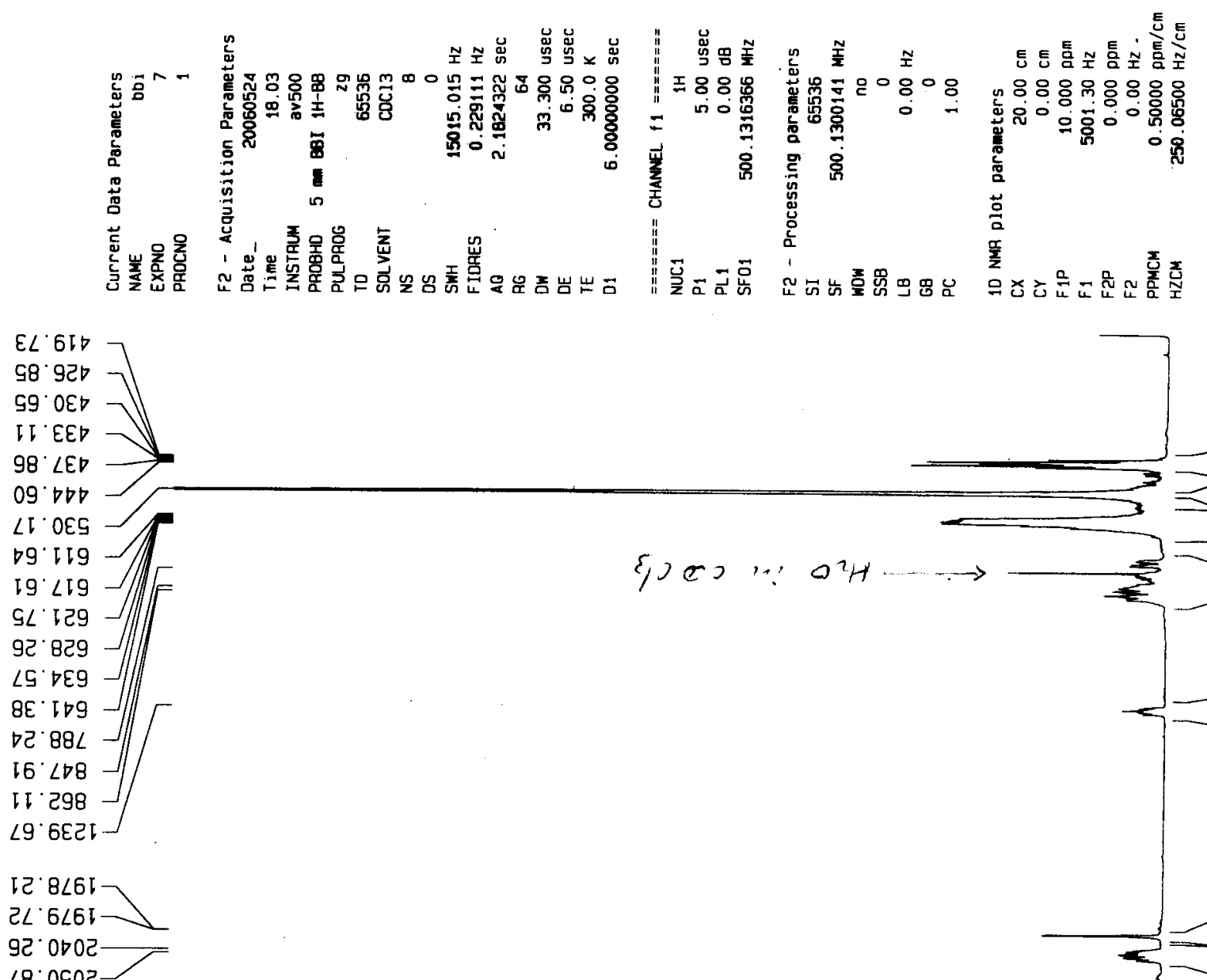

$\angle 8$ OSOC
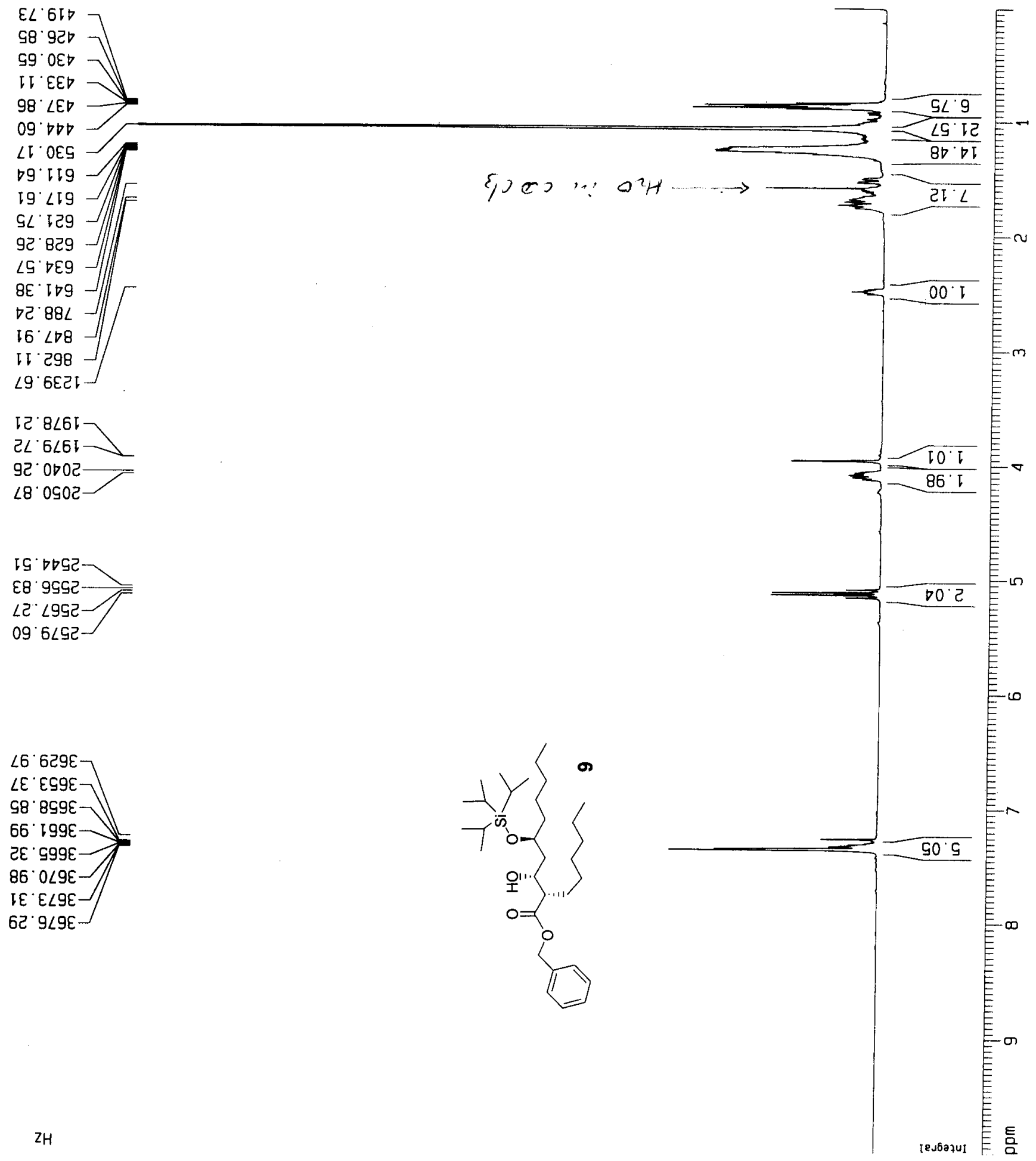


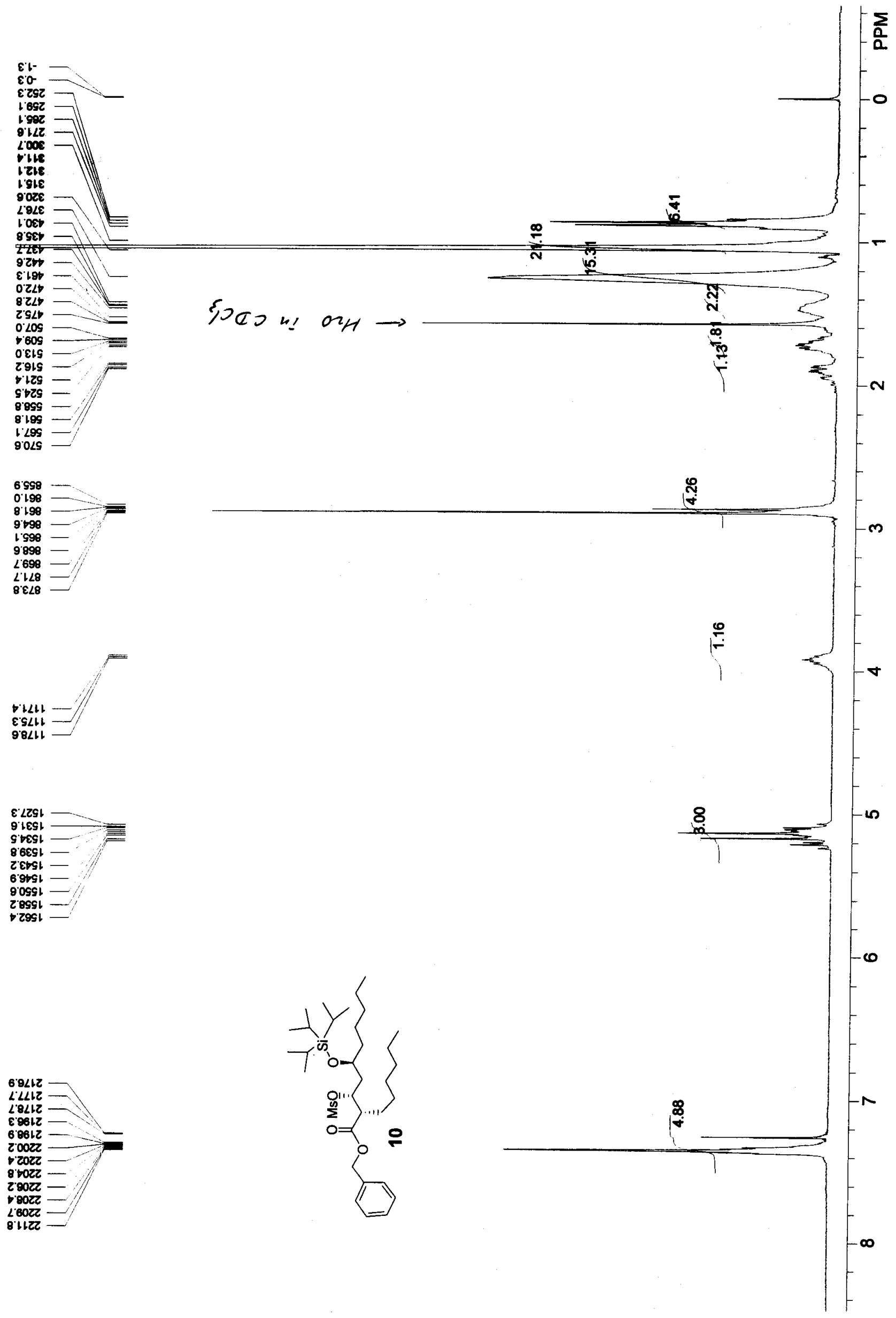




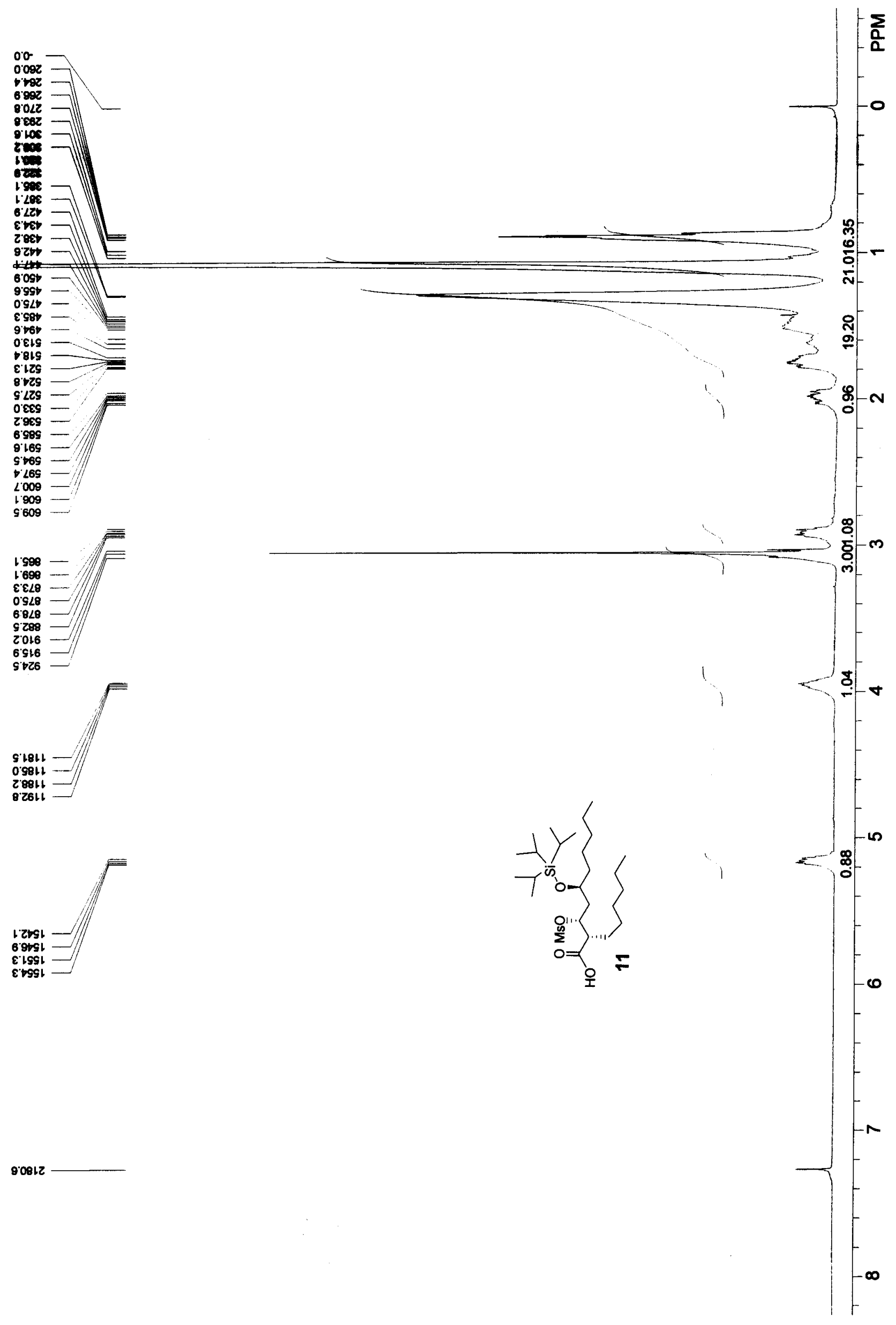




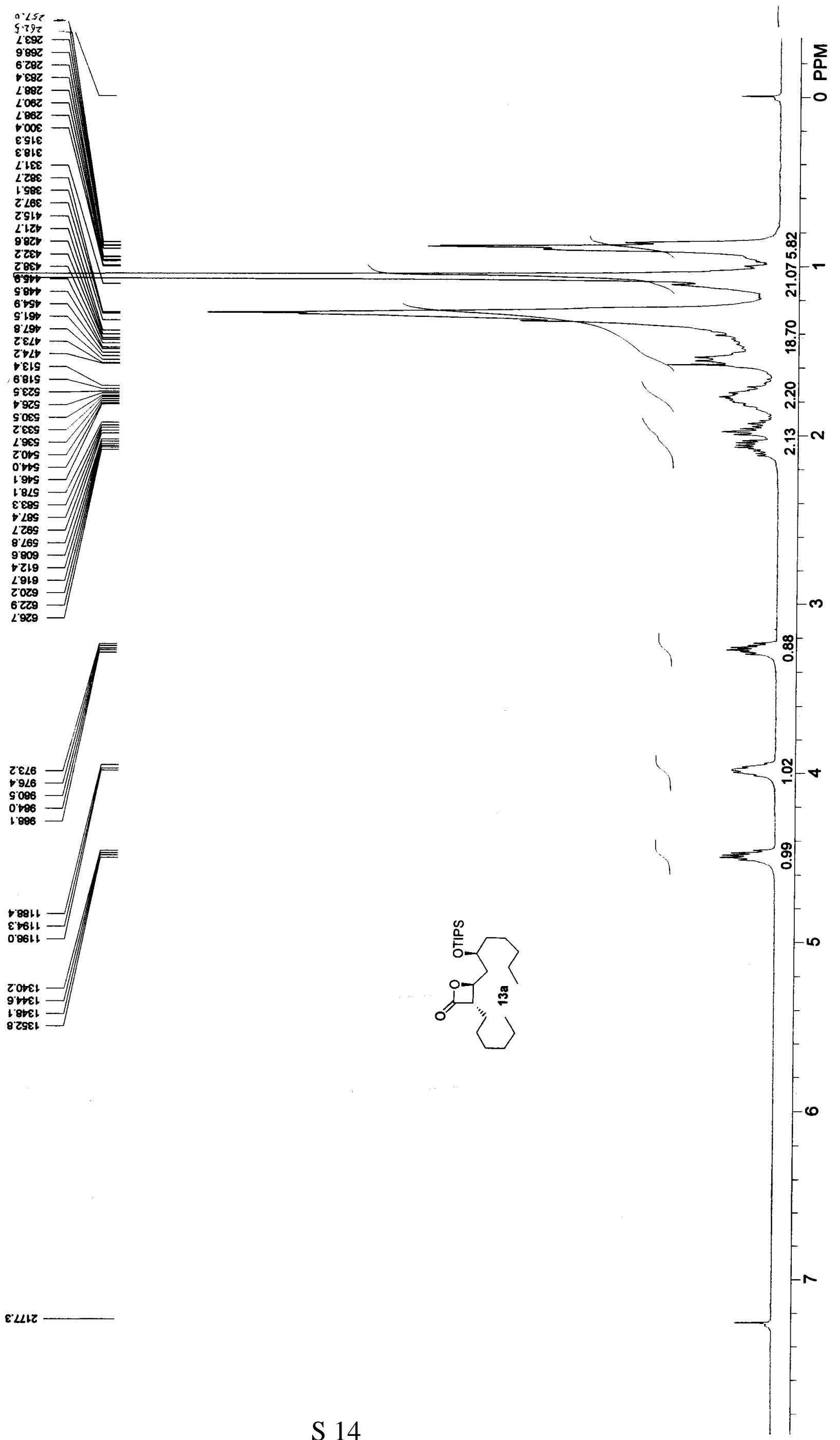



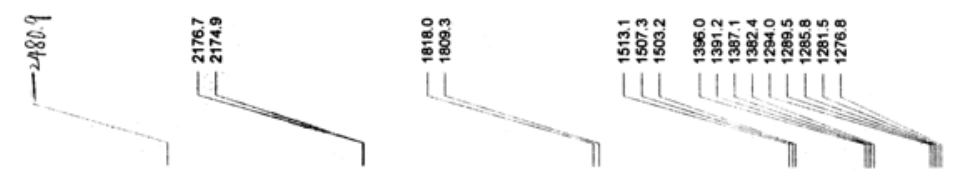

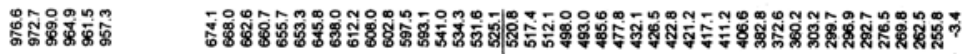

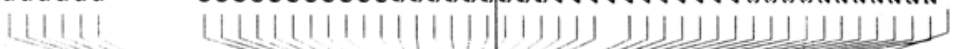

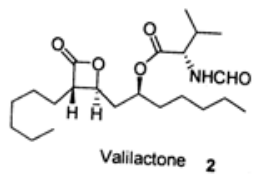

$300 \mathrm{MHz}{ }^{1} \mathrm{H} \mathrm{NMR}$ (in $\mathrm{CDCl}_{3}$ ) of synthetic 2 (this work)
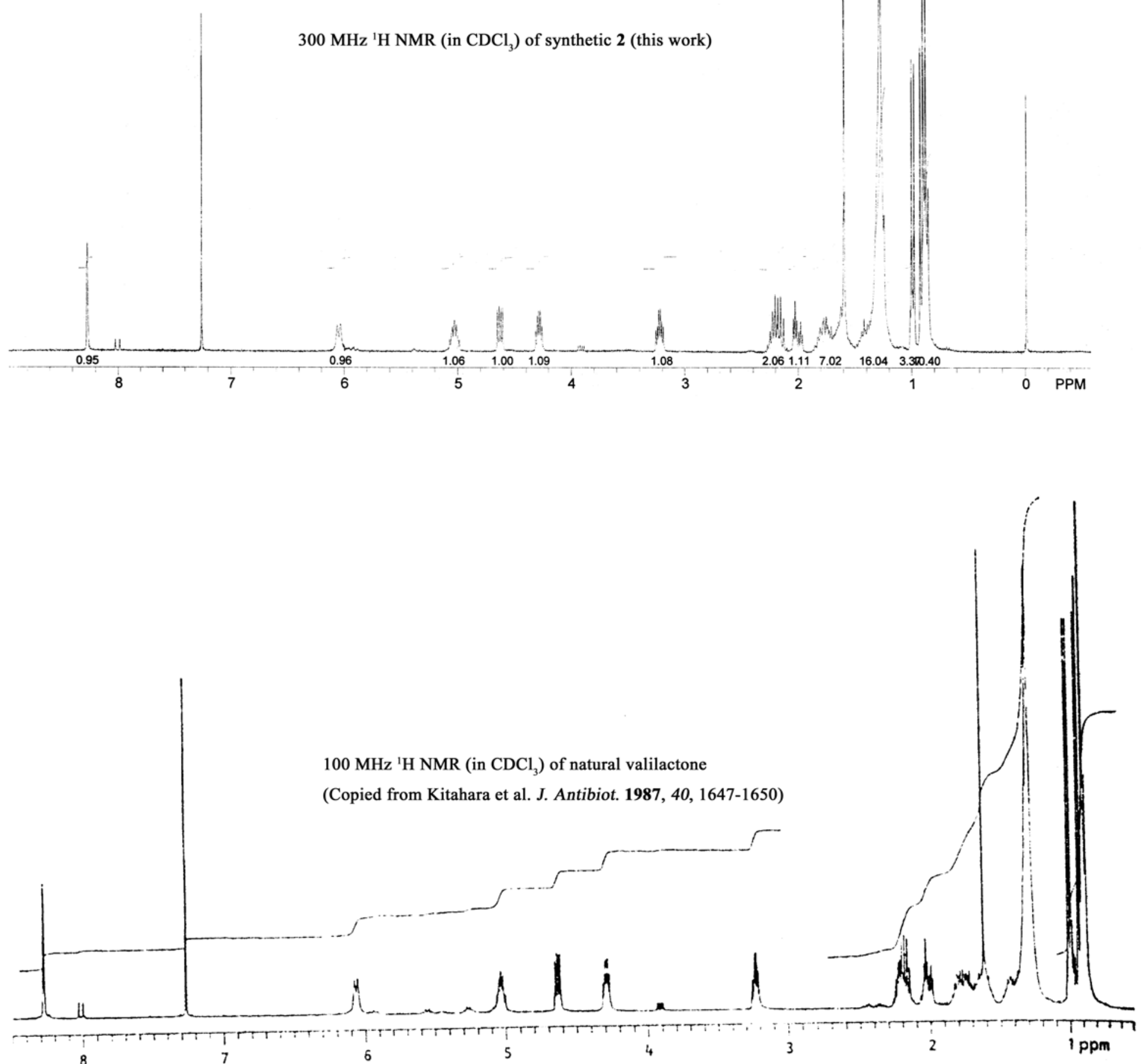